\title{
Article \\ Rethinking the Impact of Theme Park Image on Perceived Value and Behavioral Intention: The Case of Chimelong Ocean Kingdom, China
}

\author{
Chris Zhu ${ }^{1}$, Lawrence Hoc Nang Fong ${ }^{2}$, Ziye Shang ${ }^{3}$ and Manrong Gan ${ }^{4, *}$ \\ 1 School of Tourism Management, Macao Institute for Tourism Studies, Macau SAR 999078, China; \\ h210052@ift.edu.mo \\ 2 Faculty of Business Administration and Centre for Cognitive and Brain Sciences, University of Macau, \\ Macau SAR 999078, China; lawrencefong@um.edu.mo \\ 3 Faculty of International Tourism and Management, City University of Macau, Macau SAR 999078, China; \\ ziye_Shang@outlook.com \\ 4 Department of Economics, Guiyang Institute of Information Technology, Guiyang 550000, China \\ * Correspondence: t19091100165@cityu.mo
}

check for

updates

Citation: Zhu, C.; Fong, L.H.N.;

Shang, Z.; Gan, M. Rethinking the Impact of Theme Park Image on Perceived Value and Behavioral Intention: The Case of Chimelong Ocean Kingdom, China. Sustainability 2022, 14, 2349. https://doi.org/ $10.3390 /$ su14042349

Academic Editor: J. Andres Coca-Stefaniak

Received: 4 January 2022

Accepted: 15 February 2022

Published: 18 February 2022

Publisher's Note: MDPI stays neutral with regard to jurisdictional claims in published maps and institutional affiliations.

Copyright: (c) 2022 by the authors. Licensee MDPI, Basel, Switzerland. This article is an open access article distributed under the terms and conditions of the Creative Commons Attribution (CC BY) license (https:/ / creativecommons.org/licenses/by/ $4.0 /)$.

\begin{abstract}
The emergence of theme parks is enriching the tourist experience in the COVID-19 period. This study rethinks the impact of theme park image on tourist-perceived value (functional, social, and emotional value) and behavioral intention during COVID-19. Data were collected from 304 respondents who visited Chimelong Ocean Kingdom during COVID-19. This study results indicated that theme park destination image (cognitive and affective) positively predicts tourist-perceived value (functional, social, and emotional) during COVID-19. Moreover, this study also indicated that although social and emotional value positively predict tourist behavioral intention, functional value does not positively predict tourist behavioral intention during COVID-19. Theoretical and managerial implications are presented.
\end{abstract}

Keywords: theme park tourism; destination image; perceived value; behavioral intention; COVID-19

\section{Introduction}

As an essential tourism concept, destination image is defined as a person's mental representation of their beliefs and feelings about, and impressions of, a destination [1]. In order to understand the effect of destination image on tourism and its effect on tourist experience and behavior, abundant studies are focused on the composition of tourism destination image research [2,3]. For example, Beerli and Martin [2] classified the factors influencing destination image into cognitive and affection dimensions. Hallmann et al. [4] considered destination image as an interactive system that includes an integrated system of beliefs, perceptions, intentions, opinions, and emotions. On the other hand, destination image theory was also used to connect different tourist experience and behavior [5,6]. For example, previous studies found heritage destination image to positively affect tourist satisfaction and revisit intention [7]. Additionally, with the continuous impact of COVID-19 on the tourism industry, theme park-based destination image is gradually gaining more and more attention from tourists [8].

Theme parks are important leisure and tourism products that focus on providing a sense of fantasy and escape, as well as pleasurable experiences [9]. At the same time, theme parks are gradually enriching the way tourists experience the outdoors as an essential tourist destination [10]. Studies have found that the willingness of visitors to choose theme parks as a destination on weekends is gradually increasing [11]. Considering the convenience and the fact that theme parks can significantly improve the efficiency of tourists' travel, thus, theme park tourism has become more and more popular among tourists [11]. For example, Abd Aziz et al. [12] found that theme parks are motivating 
tourists to travel to a destination because of their variety of experiences and experiences compared to traditional destinations. With the continuous influence of COVID-19, tourists are becoming less selective about outdoor travel [13]. Theme parks, on the other hand, are getting more and more attention from tourists during COVID-19 because of their richness of experience as well as safety [14]. Therefore, the present study argues that exploring tourists' attitudes and behavioral intentions toward theme parks during the COVID-19 period is worthwhile for the future academic works on theme parks as well as for destination managers.

This study presents two main research gaps in the current literature. First, previous destination image studies have focused on heritage destinations, cultural destinations, etc. $[15,16]$. More importantly, most of the previous studies on destination image were conducted before COVID-19. As mentioned above, during the COVID-19 period, theme parks gradually became an important destination choice for tourists [8]. Considering that theme parks can provide visitors with rich as well as different types of themed products experiences, tourists can experience differently themed tourism and, in turn, may be more willing to visit theme park destination experiences [17]. However, to the best of our knowledge, research involving theme park destination image in the COVID-19 period is limited. Second, previous studies identified tourists' travel experiences, and post-trip behavioral intentions may be further enhanced when they are provided with a good theme park destination image [18]. For example, Cheng and Lu [19] found that when visitors gained a good destination image during the heritage destination experience, visitors' travel experience and post-trip behavioral intentions also increased further. However, when we reviewed the prior literature, few studies have re-explored the relationship of prior findings in theme park experiences under COVID-19. That is, are visitors' travel experiences and behavioral intentions further enhanced during the COVID-19 period when they have acquired a good theme park destination image? Related studies are limited.

To fill the previous research gaps, this study prompts the rethink of the impact of theme park image on tourist attitude and post-trip behavioral intention during COVID-19. The contributions of this study can be seen as threefold. First, this study is a pioneer to enriching the destination image theory regarding theme park tourism during the COVID-19 pandemic. Second, this paper rethinks the impact of theme park image on perceived value and tourist behavioral intention, which presents a theoretical reference for subsequent related studies. Third, the results of this study provide insights to destination managers on how to operate theme park tourism-that is, how they develop strategies in the two main areas of theme park destination image, three main areas of tourist-perceived value, and tourist behavioral intention to recover theme park tourism after the COVID-19 pandemic effectively.

\section{Literature Review and Hypotheses}

\subsection{Impact of COVID-19 in Tourism}

Since the coronavirus outbreak in early 2020, the COVID-19 pandemic has caused a severe economic downturn and great uncertainty for the global tourism and hospitality industry [20]. Although the Chinese government has gradually brought the COVID-19 outbreak under control by now in its current location and is recovering the tourism economy in an orderly manner [21], the outbreak continues to pose a potential threat to the tourism and hospitality industry due to the COVID-19 variants. More importantly there could be further impact on the confidence of tourists in their on-the-ground travel experience [13]. Therefore, based on this general background, tourism and hospitality industry personnel need to further explore tourists' attitudes and behavioral intentions under COVID-19 in order to make further strategic adjustments for attracting more tourists.

A significant impact of COVID-19 on tourists is the increased psychological stress [22]. For example, people may fear going out because of the transmissibility of the outbreak. When people stay at home for long periods of time, this may cause an increase in negative emotions among tourists, which in turn may even lead to psychological disorders [23]. Further, Yang et al. [24] identified that visitors' psychological stress was increasing during the 
COVID-19 period, and this psychological stress caused by COVID-19 could be effectively alleviated through information experience technology. In addition to this, a previous study also found that COVID-19 further enhances an increase in tourists' risk perceptions [25]. For example, tourists may change their travel attitudes by fearing factors such as health risks during a pandemic and thus reducing their travel spending [26]. However, there is still a portion of the study that suggests that the broader context of COVID-19 may further stimulate tourist demand for travel experiences as well as generate positive psychological consumption activities [27]. Considering that theme parks are gradually becoming one of the most important tourist attractions during COVID-19, they have already attracted many visitors' attention [28]. However, the study of tourists' attitudes and behavioral intentions towards theme parks under COVID-19 is still limited. Thus, COVID-19 provides a special context for studying the motivation and psychology of theme park visitors.

\subsection{Theme Parks in Tourism}

The theme park is defined as a relatively new form of entertainment attraction that attempts to create a fantasy atmosphere of another place and time [29]. In the present research, theme parks are divided into two main categories: amusement park and heritage park. An amusement park is defined as a recreational place that includes various rides and games to entertain visitors (e.g., Disney World) [8]. Heritage park refers to heritage attractions with a unified theme for preserving and interpreting some aspects of national culture (e.g., Timbertown, Australia) [8]. Comparing these two different types of theme parks, the former (amusement park) features various rides and games to entertain visitors and apply different themes to its rides, games, and other attractions [14]. At the same time, visitors can become part of the story through the fantasy created by creative landscapes, architecture, characters, food and other elements as they experience the entertainment nature of the theme park. On the other hand, heritage theme parks are more on a central theme that tells of the past and informs visitors about past lives, events, and cultures [8]. Previous studies have found that theme parks with virtual technology experiences that are entertaining in nature tend to be more popular among visitors during COVID-19 [30]. In addition to this, amusement theme experience interactions between friends and family may be more attractive to visitors than heritage theme parks [31]. Moreover, as many of the newest amusement theme parks have adopted information and communication technology (e.g., VR) devices to further attract visitors, visitors' willingness to travel is enhanced [17]. Based on previous considerations and inspirations, the present study focuses on amusement theme park destinations.

On the other hand, previous research has found that when theme parks create good spatiality, thematization, and technological presentations, they can significantly increase visitor satisfaction as well as behavioral intentions [32,33]. For example, a previous study found that when a theme park is filled with authenticity, this perception of authenticity enhances visitors' behavioral intentions [10]. With development and combination of information technology and tourism experiences, studies also found that visitor satisfaction and behavioral intentions were further enhanced when theme parks adopted VR technology experiences [30]. However, when we review the related literature, most of these empirical studies focused on pre-COVID-19. The continuous impact of COVID-19 on the tourism industry is foreseeable, despite the fact that the Chinese government has effectively dealt with the impact of the outbreak on the tourism industry. Considering the continuous impact of COVID-19 on the psychology and behavior of tourists traveling, how are tourists attitudes and behavioral intentions toward the theme park under COVID-19? Relevant research is limited. Exploring one of the most representative destinations-themed parks under COVID-19-is of great value to academic research and destination managers.

\subsection{Destination Image}

Destination image is commonly defined as the sum of beliefs, ideas, and impressions about a person's destination [34]. Based on this concept, destination image has been ex- 
tended by many scholars [35]. Previous research indicates there are many benefits through researching destination images. From a theoretical perspective, research on destination image can identify the relationships between destination image, tourists' satisfaction, and behavioral intentions from different countries and regions [36]. The theoretical value in destination images is relevant for tourism managers and designers to rethink the way destination images are advertised [5]. Thus, through theoretical development, research on destination can contribute to destination image literature.

From a practical perspective, it is essential to study the theme park destination image, as destination image has been studied in different countries in tourism. Prior research indicated that destination image can positively or negatively affect tourists' satisfaction and revisit intention [15]. Moreover, the study of the destination image is an effective way to advertise the tourism scenery and culture of different countries [37], stimulating tourists' intention to visit. However, most destination image research sites are different, such as cultural heritage sites; therefore, results of different destination images are hardly representative and generalizable [7]. Unlike the previously proposed destination image studies, theme park tourism is more representative and universal. Because the theme park experience is more colorful, and improves visitor efficiency, especially during the holidays compared to other tourist destinations [38], theme park research is critical for destination managers.

Previous research suggested that destination image can be divided into two dimensions, including cognitive and affective image [2]. Cognitive dimension refers to the evaluation of destination features, and may be related to weather, transportation, recreational facilities, attitudes, food, landscape, and destination locals, while the affective dimension refers to visitors' feelings or emotional reactions to the destination, more at the psychological level [1]. Numerous studies have demonstrated the relationship between cognitive image and affective image, and cognitive image positively influences affective image in tourism experience $[17,39,40]$. Based on previous literature, we propose the following hypothesis.

\section{Hypothesis 1 (H1): Cognitive image positively predicts affective image.}

\subsection{Perceived Value}

Perceived value is defined as the utility an individual derives from a tangible product or intangible service [41]. Duman and Mattila [42] argued that in a tourism experience, perceived value results from the time, cost, and effort spent on this tourism experience compared to the experience received. Kim et al. [43] argue that perceived value is an essential antecedent of customers' behavioral intentions. Wang et al. [44] further support this view by arguing that perceived value is the preference or evaluation of the destination's physical object and the services provided by the destination for the tourists during or after the tour. Thus, perceived value can be used as mediating variable in tourism to link or to de-link the relationship between antecedent and consequence variables.

Researchers interpret perceived value from two perspectives: one-dimensional and multi-dimensional. The former shows that value is a consumer's overall evaluation of a product or service [45]. The latter emphasizes that the overall evaluation could be examined based on different dimensions [46]. Current studies in tourism main refer to perceived value from multi-dimensional perspectives. For example, Prebensen et al. [47] and Eid and El-Gohary [46] identified the dimensions of perceived value comprised functional, social, and emotional values in tourism experiences. According to Shen [48]'s research, functional value refers to the facilities and infrastructure of a destination in the tourism context; social value is defined as the perceived utility obtained from the ability of a product or service to create or enhance personal images, such as reputation, social status, ethnic identity, and personal characteristics; emotional value is defined as the perceived utility of a product or a service to generate feelings or emotional changes. Based on these three dimensions of 
perceived value, abundant research has applied them in tourism studies [47]. Thus, this study refers to the three dimensions of perceived value.

Numerous studies identified the relationships between destination image and perceived value and revealed that destination image (cognitive and affective image) positively influences tourist-perceived value (functional, social, and emotional) $[49,50]$. For example, Hu et al. [49] noted a correlation between destination image and perceived value, indicating destination image (cognitive image and affective image) positively influences tourist-perceived value (emotional, functional, and social). Jeong and Kim [50] further supported previous study views and examined a structural model of destination image and perceived value and indicated that destination image (cognitive and affective) could significantly influence perceived value (emotional, functional, and social). Therefore, based on the previous literature reviews, the following hypotheses are proposed:

Hypothesis 2a (H2a): Cognitive image positively predicts tourist functional value.

Hypothesis $\mathbf{2 b}(\mathbf{H} 2 \mathbf{b})$ : Cognitive image positively predicts tourist social value.

Hypothesis 2c (H2c): Cognitive image positively predicts tourist emotional value.

Hypothesis 3a (H3a): Affective image positively predicts tourist functional value.

Hypothesis 3b (H3b): Affective image positively predicts tourist social value.

Hypothesis 3c (H3c): Affective image positively predicts tourist emotional value.

\subsection{Behavioral Intention}

Behavioral intention is defined as the quality of the actual experience after receiving the service [51]. Chang and Lin [52] argue that tourist behavioral intention mainly refers to whether tourists are willing to revisit on their next vacation, recommend to others, give positive feedback, or spread positive word-of-mouth. This understanding of behavioral intention has also been validated by many studies [53,54]. Prior studies examined the relationships between tourists' perceived value and tourist behavioral intention [15,55]. For example, Fu et al.'s [56] study found that perceived value (social, functional, and emotional) positively influences tourist behavioral intention. Other studies further supported these findings, which shows that perceived value can positively influence post-trip behavioral intention $[37,57]$. Therefore, based on the previous literature review, the following hypotheses are proposed:

Hypothesis 4 (H4): Functional value positively predicts behavioral intention.

Hypothesis 5 (H5): Social value positively predicts behavioral intention.

Hypothesis 6 (H6): Emotional value positively predicts behavioral intention.

Based on prior hypotheses, a theoretical model is illustrated in Figure 1. 


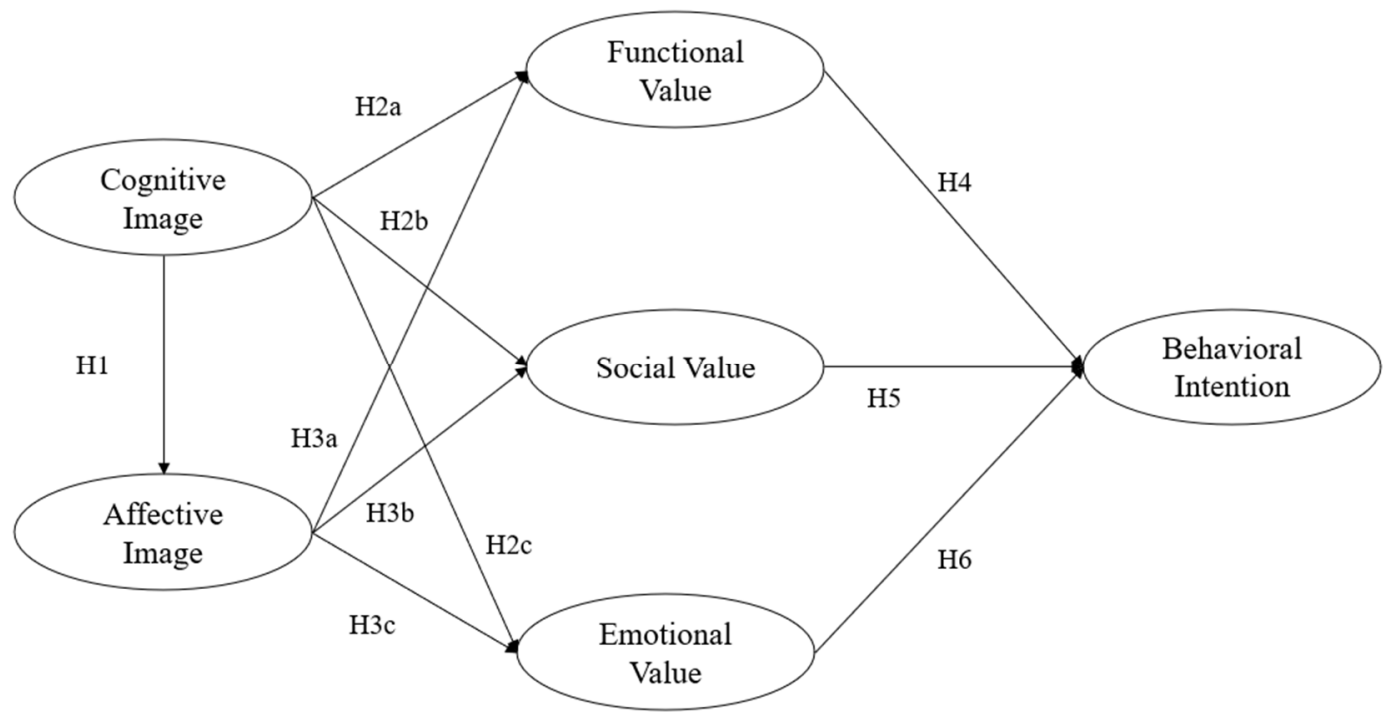

Figure 1. Research Model.

\section{Research Method}

\subsection{Study Site and Measurements}

Chimelong Ocean Kingdom Theme Park (COKTP) is the most representative theme park in China as well as in the Guangdong, Hong Kong, and Macau Bay Area (GBA) [58]. According to the previous study and official website introduction of COKTP [59], the main reasons for choosing theme parks as the research site for this study are as follows: (1) COKTP's ocean-themed area is among the largest in the world and includes many top-notch motorized games, rare animal pavilions, large theater performances, dining, shopping, and other comprehensive entertainment; (2) it has the world's largest marine fish pavilion; (3) it has the world's longest track flying roller coaster, which can take you flying through the nature of the tropical rainforest theme park; (4) it has the first water roller coaster experience in Asia, with a track length of nearly $1000 \mathrm{~m}$, going up to the sky and into the sea, allowing visitors to enjoy unlimited thematic fun; (5) it has the most massive and joyful ocean-themed float parade, including various types of marine life themes; and (6) it has the world's first large visitor facilities and precious animal exhibits to match the design, allowing visitors to experience different types of themed fun. Further, visitors can choose different types of themes to visit and meet the needs of different types and different backgrounds of visitors.

The measurements of destination image (cognitive and affective image) were adapted from Baloglu and McCleary [1] and Wang and Hsu [6]. The measurements of perceived value (functional, social, and emotional value) were adapted from Caber et al. [57]. The measurements of tourist behavioral intention were adapted from Caber et al. [57] and Zhang and Niyomsilp [37]. All measurements were adapted to fill the actual context. These measurable items were translated into Chinese, then back into English to verify the consistency, and proofread by two professional translators to ensure the reliability of the questionnaire. Then, in the end of December 2020, a field pilot study was conducted with 30 tourists visiting COKTP during COVID-19 to determine the validity of the content. The respondents indicated that they could understand the meaning of all the questions thoroughly, so no further amendments were made. All 30 pilot samples were not included in further data analysis.

\subsection{Questionnaire Design and Data Collection}

The questionnaire comprises three sections. In the first section, since respondents need to have previous experience in visiting the COKTP during the COVID-19 pandemic, a filtering question (Did you visit the Chimelong Ocean Kingdom Theme Park during 
COVID-19?) was asked. The second section of the questionnaire consisted of 28 measurable items from six constructs in the research model. All items were measured using a sevenpoint Likert scale ranging from 1 (strongly disagree) to 7 (strongly agree). The third section consisted of the respondent's background information. Table A1 in the Appendix A indicates the background information of respondents.

The study's data collection period was from 10 January 2021 to 15 March 2021. Data were collected face-to-face, and this study employed four trained research assistants to assist with data collection. Considering that the tourists of holidays mainly come from various provinces in China, the large number of tourists and the high concentration of tourists will make the data sample more representative. Therefore, data collection for this study focused on the holiday season during these 3 months, such as Christmas and holiday weekends. Convenience sampling method was used in this study. Tourists were invited to participate in the study from 9:00 a.m. to 6:00 p.m. each day during the holiday season. Respondents took approximately $20 \mathrm{~min}$ to complete the questionnaire. A total of 330 questionnaires were collected; 26 invalid questionnaires were excluded because of similar rating; and 304 questionnaires were ultimately retained.

\section{Findings}

Compared to Covariance Based SEM (CB-SEM), Partial Least Squared SEM (PLS-SEM) fits for less restrictive assumptions on normality and can handle small samples [60]. Moreover, the aim of this study is to predict the effects of theme park image on tourist-perceived value and post-trip behavioral intention rather than theory and model comparisons [61]. Therefore, this study adopted PLS-SEM as an analysis method and was conducted using Smart-PLS v.3.2.9 [62].

\subsection{Measurement Model Evaluation}

Following the steps recommended by Hair Jr et al. [60], this study first verifies the reliability and validity of the measurement model. Table 1 exhibits the mean, standard deviation (S.D.), and factor loading of 28 measurement items. The factor loadings of all indicators were above 0.7 ; the Cronbach's alpha and composite reliability of each construct were above 0.7 ; and the average variance extracted was above 0.5 , which indicated that the measurement model obtained good reliability and convergent validity (Hair Jr et al., 2017). Then, this study further tests the discriminant validity based on the Fornell-Lacker criterion and Heterotrait-Monotrait Ratio (HTMT). Table 2 indicates that the discriminant validity of the measurement model is well accepted [61]. To assess the possibility of common method bias, a Harman's factor test was conducted. The first factor produced a percentage of variance less than $50 \%$; therefore, it confirmed no obvious common method bias in the present study [63]. In addition, the values of the variance inflation factor (VIF) of the exogeneous variables (ranging from 1.334-2.238) were less than the recommended cutoff value of 5.0, and thus, there was no collinearity problem in this study [64].

Table 1. Mean, standard deviation (S.D.), and factor loading of 28 measurement items.

\begin{tabular}{|c|c|c|c|c|}
\hline \multicolumn{2}{|c|}{ Measurement Item } & Mean & S.D. & Factor Loading \\
\hline \multicolumn{5}{|c|}{ Cognitive Image (CI) } \\
\hline CI-1 & I think it has a beautiful scenery. & 5.576 & 5.576 & 0.765 \\
\hline CI-2 & I think it is a novel travel destination. & 5.424 & 5.424 & 0.751 \\
\hline CI-3 & I think it has convenient transportation. & 5.339 & 5.339 & 0.754 \\
\hline CI-4 & $\begin{array}{l}\text { I think it has quality of infrastructure and suitable } \\
\text { accommodation. }\end{array}$ & 5.421 & 5.421 & 0.775 \\
\hline CI-5 & I think it has good entertainment facilities. & 5.645 & 5.645 & 0.804 \\
\hline CI-6 & I think it has a good reputation. & 5.556 & 5.556 & 0.791 \\
\hline CI-7 & I think it safeguards my personal safety. & 5.51 & 5.51 & 0.757 \\
\hline CI-8 & I think it provides standard hygiene and cleanliness. & 5.457 & 5.457 & 0.741 \\
\hline
\end{tabular}


Table 1. Cont.

\begin{tabular}{|c|c|c|c|c|}
\hline \multicolumn{2}{|c|}{ Measurement Item } & Mean & S.D. & Factor Loading \\
\hline \multicolumn{5}{|c|}{ Affective Image (AI) } \\
\hline AI-1 & It is a pleasing travel destination. & 5.655 & 0.995 & 0.874 \\
\hline AI-2 & It is an inspired travel destination. & 5.408 & 1.096 & 0.862 \\
\hline AI-3 & It is an exciting travel destination. & 5.48 & 1.07 & 0.856 \\
\hline AI-4 & It is an enjoyable travel destination. & 5.674 & 1.074 & 0.849 \\
\hline \multicolumn{5}{|c|}{ Social Value (SV) } \\
\hline SV-1 & This tour makes me feel more socially accepted. & 4.924 & 1.191 & 0.855 \\
\hline SV-2 & This tour improves the way I am perceived. & 4.605 & 1.26 & 0.869 \\
\hline SV-3 & This tour helps me to feel acceptable to others. & 4.724 & 1.265 & 0.909 \\
\hline SV-4 & This tour enables me to impress others. & 4.799 & 1.228 & 0.855 \\
\hline \multicolumn{5}{|c|}{ Emotional Value (EV) } \\
\hline EV-1 & This tour makes me enjoyable. & 5.562 & 0.965 & 0.886 \\
\hline EV-2 & This tour makes me relaxed. & 5.52 & 1.097 & 0.859 \\
\hline EV-3 & This tour makes me happy. & 5.533 & 1.016 & 0.884 \\
\hline EV-4 & This tour makes me good. & 5.52 & 1.026 & 0.87 \\
\hline \multicolumn{5}{|c|}{ Functional Value (FV) } \\
\hline FV-1 & This tour represents 'value for money'. & 5.434 & 0.988 & 0.829 \\
\hline FV-2 & The service fees at this tour are reasonable. & 4.888 & 1.095 & 0.725 \\
\hline FV-3 & This tour has an acceptable standard of quality. & 5.457 & 1.002 & 0.857 \\
\hline FV-4 & This tour has consistent quality. & 5.421 & 1.013 & 0.838 \\
\hline \multicolumn{5}{|c|}{ Behavioral Intention (BI) } \\
\hline $\mathrm{BI}-1$ & I consider this tour as my first choice compared to other tours. & 5.243 & 1.045 & 0.853 \\
\hline BI-2 & I have a strong intention to join this tour again. & 5.138 & 1.073 & 0.863 \\
\hline $\mathrm{BI}-3$ & I would recommend it to others. & 5.444 & 1.034 & 0.842 \\
\hline BI-4 & I will tell others interesting things about the tour. & 5.566 & 1.027 & 0.787 \\
\hline
\end{tabular}

Table 2. Reliability, validity, and correlations.

\begin{tabular}{|c|c|c|c|c|c|c|c|c|c|c|c|c|c|c|}
\hline & \multirow{2}{*}{$\begin{array}{l}\text { Cronbach's } \\
\text { Alpha }\end{array}$} & \multirow[b]{2}{*}{ CR } & \multirow[b]{2}{*}{ AVE } & \multicolumn{6}{|c|}{ Fornell-Larcker Criterion } & \multicolumn{5}{|c|}{ Heterotrait-Monotrait Ratio (HTMT) } \\
\hline & & & & AI & BI & CI & EV & FV & SV & AI & BI & CI & EV & FV \\
\hline Affective image (AI) & 0.883 & 0.919 & 0.740 & 0.860 & & & & & & & & & & \\
\hline Behavioral intention (BI) & 0.857 & 0.903 & 0.700 & 0.643 & 0.837 & & & & & 0.736 & & & & \\
\hline Cognitive image (CI) & 0.900 & 0.920 & 0.589 & 0.744 & 0.617 & 0.767 & & & & 0.831 & 0.699 & & & \\
\hline Emotional value (EV) & 0.898 & 0.929 & 0.765 & 0.767 & 0.723 & 0.669 & 0.875 & & & 0.860 & 0.825 & 0.744 & & \\
\hline Functional value (FV) & 0.830 & 0.887 & 0.663 & 0.738 & 0.602 & 0.656 & 0.700 & 0.814 & & 0.851 & 0.711 & 0.752 & 0.803 & \\
\hline Social value $(\mathrm{SV})$ & 0.895 & 0.927 & 0.761 & 0.425 & 0.557 & 0.42 & 0.416 & 0.490 & 0.872 & 0.479 & 0.632 & 0.468 & 0.462 & 0.570 \\
\hline
\end{tabular}

Remark: CR = construct reliability; $\mathrm{AVE}=$ average variance extracted; Italic font = square-root of the AVE.

\subsection{Structural Model Assessment}

This study further tests the hypotheses using the bootstrap method under 5000 samples and aims to examine the statistical significance of the hypothesized model [61]. Table 3 exhibits the results of the PLS-SEM analysis. The coefficient of determination of endogenous constructs ( $\mathrm{R}$ square value) is above 0.2 , indicating the structural model's accepted predictive power [61]. The result of PLS analysis indicated that cognitive image has a significant effect on affective image and also indicated that destination image (cognitive and affective) has a significant effect on tourist-perceived value (functional, social, and emotional) $(\beta=0.744$, t-statistics $=22.795, p$-value $=0.000 ; \beta=0.239$, $\mathrm{t}$-statistics $=3.637, \mathrm{p}$-value $=0.000 ;$ $\beta=0.231$, t-statistics $=3.23, p$-value $=0.003 ; \beta=0.221, \mathrm{t}$-statistics $=3.644, p$-value $=0.000 ;$ $\beta=0.561$, t-statistics $=9.55, p$-value $=0.000 ; \beta=0.253, \mathrm{t}$-statistics $=2.968, \mathrm{p}$-value $=0.000 ;$ $\beta=0.603$, t-statistics $=9.49$, $p$-value $=0.000)$, supporting $\mathrm{H} 1, \mathrm{H} 2 \mathrm{a}, \mathrm{H} 2 \mathrm{~b}, \mathrm{H} 2 \mathrm{c}, \mathrm{H} 3 \mathrm{a}, \mathrm{H} 3 \mathrm{~b}$, and $\mathrm{H} 3 \mathrm{c}$. The results of PLS analysis also indicated the relationships between tourist perceived value (functional, social, and emotional) and tourist behavioral intention. The path coefficient, $\mathrm{t}$-statistics and $\mathrm{p}$-value indicated $\beta=0.074$, $\mathrm{t}$-statistics $=1.239, p$-value $=0.215 ; \beta=0.292$, $\mathrm{t}$-statistics $=5.59, p$-value $=0.001 ; \beta=0.55, \mathrm{t}$-statistics $=9.902, p$-value $=0.000$, supporting H5 and H6, whereas H4 is not supported. To assess whether the omitted constructs had a substantial effect on the endogenous ones, the present study tested the effects of f-square 
values. The results present the effect size f-square values for the significant paths ranged from $0.03-1.238$ and showed that the influence of destination image on perceived value and behavioral intention ranged from small to large [65].

Table 3. Results of the hypothesized model using PLS.

\begin{tabular}{|c|c|c|c|c|c|c|}
\hline & & Path Coefficient & t-Value & f-Square & $p$-Value & Supported? \\
\hline H1 & $\mathrm{CI} \rightarrow \mathrm{AI}$ & 0.744 & 22.795 & 1.238 & 0.000 & Yes \\
\hline $\mathrm{H} 2 \mathrm{a}$ & $\mathrm{CI} \rightarrow \mathrm{FV}$ & 0.239 & 3.637 & 0.059 & 0.000 & Yes \\
\hline $\mathrm{H} 3 \mathrm{a}$ & $\mathrm{AI} \rightarrow \mathrm{FV}$ & 0.561 & 9.55 & 0.328 & 0.000 & Yes \\
\hline $\mathrm{H} 2 \mathrm{~b}$ & $\mathrm{CI} \rightarrow \mathrm{SV}$ & 0.231 & 3.23 & 0.03 & 0.000 & Yes \\
\hline $\mathrm{H} 3 \mathrm{~b}$ & $\mathrm{AI} \rightarrow \mathrm{SV}$ & 0.253 & 2.968 & 0.036 & 0.003 & Yes \\
\hline $\mathrm{H} 2 \mathrm{c}$ & $\mathrm{CI} \rightarrow \mathrm{EV}$ & 0.221 & 3.644 & 0.056 & 0.000 & Yes \\
\hline $\mathrm{H} 3 \mathrm{c}$ & $\mathrm{AI} \rightarrow \mathrm{EV}$ & 0.603 & 9.49 & 0.417 & 0.000 & Yes \\
\hline $\mathrm{H} 4$ & $\mathrm{FV} \rightarrow \mathrm{BI}$ & 0.074 & 1.239 & 0.006 & 0.215 & No \\
\hline H5 & $\mathrm{SV} \rightarrow \mathrm{BI}$ & 0.292 & 5.59 & 0.162 & 0.001 & Yes \\
\hline H6 & $\mathrm{EV} \rightarrow \mathrm{BI}$ & 0.55 & 9.902 & 0.385 & 0.000 & Yes \\
\hline
\end{tabular}

Notes: $R^{2}$ value for $A I=0.553, R^{2}$ value for $F V=0.571, R^{2}$ value for $S V=0.205, R^{2}$ value for $E V=0.61, R^{2}$ value for $\mathrm{BI}=0.605$.

\subsection{Direct, Indirect, and Total Effects}

Table 4 indicates the direct, indirect, and total effects of destination image (cognitive and affective), perceived value (functional, social, and emotional), and behavioral intention. For the functional value, the cognitive image indicates a higher total effect than the affective image ( 0.656 and 0.561 , respectively). For the social value, the cognitive value shows a higher effect than the affective image ( 0.42 and 0.253 , respectively). For the emotional value, the cognitive value shows a higher effect than the affective image ( 0.669 and 0.603 , respectively). Comparing the effects of three perceived values on behavioral intention, emotional value shows a higher total effect on behavioral intention than social value (0.55 and 0.292, respectively). Meanwhile, results that indicated functional value does not significantly affect the behavioral intention (0.074).

Table 4. Direct, indirect, and total effects.

\begin{tabular}{|c|c|c|c|c|c|c|c|c|c|c|c|c|c|}
\hline & \multirow{2}{*}{$\underset{\text { Direct }}{\text { AI }}$} & \multicolumn{3}{|c|}{ Functional Value } & \multicolumn{3}{|c|}{ Social Value } & \multicolumn{3}{|c|}{ Emotional Value } & \multicolumn{3}{|c|}{ Behavioral Intention } \\
\hline & & Direct & $\begin{array}{c}\text { Total } \\
\text { Indirect }\end{array}$ & $\begin{array}{l}\text { Total } \\
\text { Effect }\end{array}$ & Direct & $\begin{array}{c}\text { Total } \\
\text { Indirect }\end{array}$ & $\begin{array}{l}\text { Total } \\
\text { Effect }\end{array}$ & Direct & $\begin{array}{c}\text { Total } \\
\text { Indirect }\end{array}$ & $\begin{array}{l}\text { Total } \\
\text { Effect }\end{array}$ & Direct & $\begin{array}{c}\text { Total } \\
\text { Indirect }\end{array}$ & $\begin{array}{l}\text { Total } \\
\text { Effect }\end{array}$ \\
\hline $\mathrm{CI}$ & $0.744^{* * *}$ & $0.239 * * *$ & $0.417^{* * *}$ & $0.656^{* * *}$ & $0.231 * * *$ & $0.189 * * *$ & $0.42 * * *$ & $0.221 * * *$ & $0.448^{* * *}$ & $0.669 * * *$ & - & $0.539 * * *$ & $0.539 * * *$ \\
\hline AI & - & $0.561^{* * *}$ & - & $0.561^{* * *}$ & 0.253 * & - & 0.253 * & $0.603^{* * *}$ & - & $0.603^{* * *}$ & - & $0.447^{* * *}$ & $0.447^{* * *}$ \\
\hline FI & - & - & - & - & - & - & - & - & - & - & $0.074^{\mathrm{ns}}$ & - & $0.074^{\mathrm{ns}}$ \\
\hline SV & - & - & - & - & - & - & - & - & - & - & $0.292^{* *}$ & - & 0.292 ** \\
\hline FI & - & - & - & - & - & - & - & - & - & - & $0.55^{* * *}$ & - & $0.55^{* * *}$ \\
\hline
\end{tabular}

Notes: ns, not significant, ${ }^{* * *} p<0.001,{ }^{* *} p<0.01,{ }^{*} p<0.05$.

\section{Discussion}

As the impact of COVID-19 on the global pandemic continues to rise, theme park destinations receive increasing attention during the COVID-19 period [8]. The present study found that when theme park destinations create a good cognitive image of the destination during the COVID-19 period, the tourist affective image of the theme park destination is further enhanced by tourists (H1). This finding is consistent with previous empirical studies based on different destination studies prior to COVID-19 [66,67]. Considering that cognitive image emphasizes more of an external objective factor, such as theme park equipment experience with distinctive objects, the affective image, on the other hand, emphasizes more of a psychological consideration [1]. Further, affective image suggests that when a destination creates a good emotional factor, the visitor's affective image will also be significantly higher [2]. This may be because, despite the impact of COVID-19, at COKTP, the external device experience, the different tourist themes, are still functioning properly, and visitors can still have a good tourist experience. 
Further, this study also found that when visitors receive a good cognitive and affective image, visitors will receive good functional, social, and emotional value $(H 2 a, H 2 b, H 2 c$, $H 3 a, H 3 b$, and $H 3 c$ ). This finding supports the previous relationship between destination image and visitors' perceived value pre-COVID-19 and further extends their relationship in the theme park experience during COVID-19 [35,37]. According to Shen [48]'s research, functional value refers to the perceived value of the facilities and infrastructure of a theme park destination with more emphasis. Social value, on the other hand, emphasizes the perceived utility of creating or enhancing a visitor's personal image when they experience a theme park product or service. For example, when visitors visit a theme park, they can take pictures and upload them to social media platforms to get comments or likes from friends and family, which may further enhance the social value of visitors [67]. Finally, emotional value focuses more on the perceived utility of emotional or mood changes when visitors experience theme park products or services. Additionally, as COKTP emphasizes more on the diversity and richness of theme park facilities, through different types of scene features, theme features, especially marine themes and adventure themes, and various entertainment experiences, visitors can get different levels of perceived value experience. This further help us understand why the three different perceived values of visitors are significantly increased when they are given a good destination image.

Finally, this study also found that visitors' behavioral intentions are further enhanced when they receive good social and emotional values $(\mathrm{H} 5, \mathrm{H6})$. This finding supports the findings of previous studies $[15,68]$ and is further corroborated in the theme park during COVID-19. Considering that social and emotional value experiences place more emphasis on the inner psychological feelings of visitors [48], COKTP did its best to keep visitors from experiencing some psychological stress during the COVID-19 pandemic. For example, visitors may be concerned that COVID-19 may cause them to worry about safety hazards. The theme park's corresponding safety measures and other factors will also ensure that visitors can play with peace of mind as much as possible. This may explain why, despite the good social and emotional value of COVID-19, visitors' behavioral intentions are further enhanced. In addition, this study also found that visitors' behavioral intentions did not increase significantly when they received functional value $(\mathrm{H} 4)$. Considering that the COVID-19 pandemic has limited the development of mass tourism experience facilities, such as large scale thematic programs, which visitors may not experience [20], this particular situation limits the experience of some famous attractions. Further, based on the definition of functional value, it will be mainly affected by the hardware facilities of the specific theme park experience. Therefore, when the hardware facilities are inadequate, the impact on tourists' travel experience and behavioral intention is naturally not significant. This finding is inconsistent with the findings of pre-COVID-19 destination image studies, but the results of this study can help academic research as well as destination managers rethink how to develop theme park tourism under COVID-19.

\section{Conclusions}

This study aims to rethink the relationship between theme park image (cognitive and emotional image), perceived value (functional, social, and emotional values), and post-trip behavioral intention during COVID-19. Furthermore, the findings show that all hypotheses are supported, except for $\mathrm{H} 4$ (Functional value has no significant effect on the behavioral intention during COVID-19). This study fills the research gap on theme park tourism research during COVID-19 and provides local governments and destination managers with new perspectives that can help them adjust their operational strategies during COVID-19. Additionally, this study is a pioneer in the COVID-19 era because it rethinks the effect of COVID-19 on theme park tourism and its impact on tourist experience and behavior. Moreover, the essential theoretical and practical implications of this study are discussed. 


\subsection{Theoretical Contributions}

Firstly, this study contributes to the study of theme park destination image. Previous studies involving destination image research have mainly focused on heritage as well as cultural tourism destinations [7]. With the continuous impact of COVID-19 on tourism, the theme park experience has gradually become an important destination choice for tourists during the COVID-19 pandemic [14], considering that theme park destinations are diverse in experience types because of their efficiency. However, when reviewing previous studies, most of the studies involving theme park destinations have mostly focused on the pre-COVID-19 period [10]. The present study fills this research gap by examining the attitudes and behavioral intentions of visitors to theme parks in the COVID-19. Inspired by these essential findings, future related research can continue to explore the influence of theme park image destinations on other psychological behaviors and intentions of visitors under COVID-19.

Furthermore, this study also contributes to the study of tourists' perceived values under COVID-19. Perceived value plays an important role in visitors' tourism experience, and previous studies have suggested that visitors' behavioral intentions are further enhanced when they have obtained good perceived value $[15,69]$. For example, Chen and Chen (2010) found that tourist satisfaction and behavioral intention are also further enhanced when tourists obtain good perceived value in heritage tourism experiences. However, studies involving the perceived value of tourists in theme park destination studies are limited, and especially few studies have examined these three dimensions (functional, social, and emotional value) of perceived value simultaneously, as well as the impact of tourists' perceived value on tourists' subsequent behavior under COVID-19. The present study fills the previous research gap. Further, future research can further explore their important role in tourists' travel experience based on the three dimensions of perceived value.

Moreover, this study also contributes to the post-trip behavioral intention literatures in the COVID-19 pandemic. Previous studies found that when tourists get a good tour experience, tourists' post-trip behavior is also significantly enhanced [70]. Inspired by this, the present study re-examined the effect of this relationship on tourists' post-trip behavior when they have received a good perceived value. Results indicated that visitors' subsequent behavioral intentions are enhanced when they receive good social and emotional value during COVID-19. This finding is consistent with previous COVID-19 research involving tourism destinations [12] and was further tested in the theme park experience under COVID-19. However, it may be because COKTP was influenced by the opening of COVID-19 to tourism venues; thus, the present study found that the functional value of visitors did not significantly enhance visitors' behavioral intentions. Finally, this study provides theoretical inspiration for future research on theme park destinations based on COVID-19 as well as for destination managers. In addition to this, this study provides significant practical implications for destination managers.

\subsection{Implications for Business Practice}

This study also provides important practical implications for local governments and destination managers to adapt the development of theme park tourism during the COVID-19 pandemic. To begin with, this study identified that when visitors are provided with a good theme park destination image, the perceived image that visitors receive can significantly enhance the emotional image, and both images can significantly enhance visitors' perceived value. Considering that the two dimensions of destination image are mainly based on the venue equipment provided by the theme park and the visitors' intrinsic experience feelings, therefore, it is essential for local governments as well as destination managers to continue to enhance the variety of theme park experience facilities and enrich the way visitors experience tourism. In turn, when providing a good destination image, it will affect the perceived value gained by visitors during COVID-19.

Second, this study also examined the effects of the three dimensions in perceived value (functional, social, and emotional value) on tourists' behavioral intentions. Results 
identified that social and emotional value remained significant in their influences on tourists post-trip behavioral intentions. Considering these two dimensions of perceived value focus more on tourists' internal emotions, local governments and destination managers should continue to consider improving the theme park product services. For example, through providing some thematic tourism products with CTKOP characteristics, tourists can share them through social media and other channels, which may enhance the social value and emotional value of tourists.

Finally, this study identified functional value as part of another important perceived value. Functional value did not have a significant effect on tourists' behavioral intentions. Due to the impact of COVID-19 in tourism, the fact of risk management and closure of some tourist facilities may have had an impact on the functional value of tourists, considering too many people gathered. Inspired by this, local destination managers should reorganize and improve more themed activities, entertainment facilities, and convenient transportation and ensure visitor safety, which may effectively improve the perceived functional value during COVID-19. In addition, theme park managers should avoid over-commercialization while developing theme park tourism and maintaining its unique character during and after COVID-19. Moreover, there are some limitations in the present study.

\subsection{Limitations and Future Study}

This study has two major limitations. First, under the policy limitations of COVID-19 in China, the sample was mainly focused on Chinese tourists. Therefore, future studies should collect a larger sample size from different countries and regions to explore their tourism attitudes toward theme park destinations during the COVID-19 pandemic. Second, different countries have different cultural and scenic tourism backgrounds, and this study may be only applicable to domestic-related theme park studies but not necessarily to foreign-related theme park studies. Therefore, based on the inspiration of this study, future studies could explore theme park tourism in other different countries and cities during the COVID-19 pandemic.

Author Contributions: Conceptualization, C.Z.; methodology, Z.S.; software, Z.S. writing-original draft preparation, Z.S.; writing-review and editing, L.H.N.F.; supervision, L.H.N.F.; project administration, M.G. All authors have read and agreed to the published version of the manuscript.

Funding: This research received no external funding.

Institutional Review Board Statement: Ethical review and approval were waived for this study, due to the collected data were based on respondents whose answers remain anonymous.

Informed Consent Statement: Informed consent was obtained from all subjects involved in the study.

Data Availability Statement: Not applicable.

Conflicts of Interest: The authors declare no conflict of interest.

\section{Appendix A}

Table A1. Background of respondents $(N=304)$.

\begin{tabular}{llcc}
\hline & & Frequency & Percent \\
\hline \multirow{2}{*}{ Gender } & Males & 134 & 44.1 \\
& Females & 170 & 55.9 \\
\hline \multirow{2}{*}{ Age } & $19-30$ & 228 & 75 \\
& $31-40$ & 41 & 13.5 \\
& $41-50$ & 24 & 7.9 \\
& $51-60$ & 7 & 2.3 \\
& Over 60 & 4 & 1.3 \\
\hline
\end{tabular}


Table A1. Cont.

\begin{tabular}{llcc}
\hline & & Frequency & Percent \\
\hline \multirow{4}{*}{ Education } & High School or below & 6 & 2.0 \\
& Junior College & 18 & 5.9 \\
& Undergraduate & 200 & 65.8 \\
& Postgraduate & 80 & 26.3 \\
\hline \multirow{3}{*}{ Income } & CNY4000 or below & 163 & 53.6 \\
(Individual monthly) & CNY4001-7000 & 76 & 25.0 \\
& CNY7001-10,000 & 48 & 15.8 \\
& CNY10001-15,000 & 13 & 4.3 \\
& Over CNY15,000 & 4 & 1.3 \\
\hline \multirow{5}{*}{ Job } & Student & 166 & 54.61 \\
& Worker/Staff & 41 & 13.49 \\
& Public Institution Employees & 51 & 16.78 \\
& Civil Servants & 20 & 6.58 \\
& Freelancers & 26 & 8.55 \\
\hline
\end{tabular}

\section{References}

1. Baloglu, S.; McCleary, K.W. A Model of Destination Image Formation. Ann. Tour. Res. 1999, 26, 868-897. [CrossRef]

2. Beerli, A.; Martin, J.D. Factors Influencing Destination Image. Ann. Tour. Res. 2004, 31, 657-681. [CrossRef]

3. Chen, C.-Y. Influence of Celebrity Involvement on Place Attachment: Role of Destination Image in Film Tourism. Asia Pac. J. Tour. Res. 2018, 23, 1-14. [CrossRef]

4. Hallmann, K.; Zehrer, A.; Müller, S. Perceived Destination Image: An Image Model for a Winter Sports Destination and Its Effect on Intention to Revisit. J. Travel Res. 2015, 54, 94-106. [CrossRef]

5. Sharma, P.; Nayak, J.K. Testing the Role of Tourists' Emotional Experiences in Predicting Destination Image, Satisfaction, and Behavioral Intentions: A Case of Wellness Tourism. Tour. Manag. Perspect. 2018, 28, 41-52. [CrossRef]

6. Wang, C.; Hsu, M.K. The Relationships of Destination Image, Satisfaction, and Behavioral Intentions: An Integrated Model. J. Travel Tour. Mark. 2010, 27, 829-843. [CrossRef]

7. Su, D.N.; Nguyen, N.A.N.; Nguyen, Q.N.T.; Tran, T.P. The Link between Travel Motivation and Satisfaction towards a Heritage Destination: The Role of Visitor Engagement, Visitor Experience and Heritage Destination Image. Tour. Manag. Perspect. 2020, 34, 100634. [CrossRef]

8. Li, B.; Zhang, T.; Hua, N.; Jahromi, M.F. Developing an Overarching Framework on Theme Park Research: A Critical Review Method. Curr. Issues Tour. 2021, 24, 2821-2837. [CrossRef]

9. Pikkemaat, B.; Schuckert, M. Success Factors of Theme Parks-An Exploration Study. Tour. Int. Interdiscip. J. 2007, 55, 197-208.

10. Duan, X.; Chan, C.; Marafa, L.M. Does Authenticity Exist in Cultural Theme Parks? A Case Study of Millennium City Park in Henan, China. J. Tour. Cult. Change 2019, 17, 321-338. [CrossRef]

11. Shinde, K.A. Religious Theme Parks as Tourist Attraction Systems. J. Herit. Tour. 2021, 16, 281-299. [CrossRef]

12. Abd Aziz, N.; Ariffin, A.A.M.; Omar, N.A.; Evin, C. Examining the Impact of Visitors' Emotions and Perceived Quality towards Satisfaction and Revisit Intention to Theme Parks (Kajian Kesan Emosi Dan Tanggapan Kualiti Pengunjung Terhadap Kepuasan Dan Hasrat Berkunjung Semula Ke Taman Tema). J. Pengur. (UKM J. Manag.) 2012, 35.

13. Wen, J.; Kozak, M.; Yang, S.; Liu, F. COVID-19: Potential Effects on Chinese Citizens' Lifestyle and Travel. Tour. Rev. 2020, 76, 74-87. [CrossRef]

14. Liang, Z.; Li, X. What Is a Theme Park? A Synthesis and Research Framework. J. Hosp. Tour. Res. 2021. [CrossRef]

15. Chen, C.-F.; Chen, F.-S. Experience Quality, Perceived Value, Satisfaction and Behavioral Intentions for Heritage Tourists. Tour. Manag. 2010, 31, 29-35. [CrossRef]

16. Huete Alcocer, N.; López Ruiz, V.R. The Role of Destination Image in Tourist Satisfaction: The Case of a Heritage Site. Econ. Res. Ekon. Istraživanja 2020, 33, 2444-2461. [CrossRef]

17. Wei, W.; Zheng, Y.; Zhang, L.; Line, N. Leveraging Customer-to-Customer Interactions to Create Immersive and Memorable Theme Park Experiences. J. Hosp. Tour. Insights 2021, in press. [CrossRef]

18. Lin, C.-H.; Morais, D.B.; Kerstetter, D.L.; Hou, J.-S. Examining the Role of Cognitive and Affective Image in Predicting Choice across Natural, Developed, and Theme-Park Destinations. J. Travel Res. 2007, 46, 183-194. [CrossRef]

19. Cheng, T.-M.; Lu, C.-C. Destination Image, Novelty, Hedonics, Perceived Value, and Revisiting Behavioral Intention for Island Tourism. Asia Pac. J. Tour. Res. 2013, 18, 766-783. [CrossRef]

20. Foroudi, P.; Tabaghdehi, S.A.H.; Marvi, R. The Gloom of the COVID-19 Shock in the Hospitality Industry: A Study of Consumer Risk Perception and Adaptive Belief in the Dark Cloud of a Pandemic. Int. J. Hosp. Manag. 2021, 92, 102717. [CrossRef]

21. Yu, X.; Li, N.; Dong, Y. Observation on China's Strategies to Prevent the Resurgence of the COVID-19 Epidemic. Risk Manag. Healthc. Policy 2021, 14, 2011. [CrossRef] [PubMed] 
22. Zheng, D.; Luo, Q.; Ritchie, B.W. Afraid to Travel after COVID-19? Self-Protection, Coping and Resilience against Pandemic 'Travel Fear'. Tour. Manag. 2021, 83, 104261. [CrossRef]

23. Chua, B.-L.; Al-Ansi, A.; Lee, M.J.; Han, H. Impact of Health Risk Perception on Avoidance of International Travel in the Wake of a Pandemic. Curr. Issues Tour. 2021, 24, 985-1002. [CrossRef]

24. Yang, T.; Lai, I.K.W.; Fan, Z.B.; Mo, Q.M. The Impact of a $360^{\circ}$ Virtual Tour on the Reduction of Psychological Stress Caused by COVID-19. Technol. Soc. 2021, 64, 101514. [CrossRef]

25. Altuntas, F.; Gok, M.S. The Effect of COVID-19 Pandemic on Domestic Tourism: A DEMA ${ }^{\text {TEL }}$ Method Analysis on Quarantine Decisions. Int. J. Hosp. Manag. 2021, 92, 102719. [CrossRef] [PubMed]

26. Fotiadis, A.; Polyzos, S.; Huan, T.-C.T. The Good, the Bad and the Ugly on COVID-19 Tourism Recovery. Ann. Tour. Res. 2021, 87, 103117. [CrossRef]

27. Cheung, C.; Takashima, M.; Choi, H.; Yang, H.; Tung, V. The Impact of COVID-19 Pandemic on the Psychological Needs of Tourists: Implications for the Travel and Tourism Industry. J. Travel Tour. Mark. 2021, 38, 155-166. [CrossRef]

28. Milman, A.; Tasci, A.D.; Wei, W. Crowded and Popular: The Two Sides of the Coin Affecting Theme-Park Experience, Satisfaction, and Loyalty. J. Destin. Mark. Manag. 2020, 18, 100468. [CrossRef]

29. Tasci, A.D.; Milman, A. Exploring Experiential Consumption Dimensions in the Theme Park Context. Curr. Issues Tour. 2019, 22, 853-876. [CrossRef]

30. Lu, J.; Xiao, X.; Xu, Z.; Wang, C.; Zhang, M.; Zhou, Y. The Potential of Virtual Tourism in the Recovery of Tourism Industry during the COVID-19 Pandemic. Curr. Issues Tour. 2021, 25, 441-457. [CrossRef]

31. Dong, P.; Siu, N.Y.-M. Servicescape Elements, Customer Predispositions and Service Experience: The Case of Theme Park Visitors. Tour. Manag. 2013, 36, 541-551. [CrossRef]

32. Waysdorf, A.; Reijnders, S. Immersion, Authenticity and the Theme Park as Social Space: Experiencing the Wizarding World of Harry Potter. Int. J. Cult. Stud. 2018, 21, 173-188. [CrossRef]

33. Zhang, Y.; Li, X.R.; Su, Q.; Hu, X. Exploring a Theme Park's Tourism Carrying Capacity: A Demand-Side Analysis. Tour. Manag. 2017, 59, 564-578. [CrossRef]

34. Crompton, J.L. An Assessment of the Image of Mexico as a Vacation Destination and the Influence of Geographical Location upon That Image. J. Travel Res. 1979, 17, 18-23. [CrossRef]

35. Moon, K.-S.; Ko, Y.J.; Connaughton, D.P.; Lee, J.-H. A Mediating Role of Destination Image in the Relationship between Event Quality, Perceived Value, and Behavioral Intention. J. Sport Tour. 2013, 18, 49-66. [CrossRef]

36. Palau-Saumell, R.; Forgas-Coll, S.; Amaya-Molinar, C.M.; Sánchez-García, J. Examining How Country Image Influences Destination Image in a Behavioral Intentions Model: The Cases of Lloret De Mar (Spain) and Cancun (Mexico). J. Travel Tour. Mark. 2016, 33, 949-965. [CrossRef]

37. Zhang, B.; Niyomsilp, E. The Relationship Between Tourism Destination Image, Perceived Value and Post-Visiting Behavioral Intention of Chinese Tourist to Thailand. Int. Bus. Res. 2020, 13, 1-96. [CrossRef]

38. Ma, J.; Gao, J.; Scott, N.; Ding, P. Customer Delight from Theme Park Experiences: The Antecedents of Delight Based on Cognitive Appraisal Theory. Ann. Tour. Res. 2013, 42, 359-381. [CrossRef]

39. Hernández-Mogollón, J.M.; Duarte, P.A.; Folgado-Fernández, J.A. The Contribution of Cultural Events to the Formation of the Cognitive and Affective Images of a Tourist Destination. J. Destin. Mark. Manag. 2018, 8, 170-178. [CrossRef]

40. Lee, J.-S.; Hsu, L.-T.; Han, H.; Kim, Y. Understanding How Consumers View Green Hotels: How a Hotel's Green Image Can Influence Behavioural Intentions. J. Sustain. Tour. 2010, 18, 901-914. [CrossRef]

41. Zeithaml, V.A. Consumer Perceptions of Price, Quality, and Value: A Means-End Model and Synthesis of Evidence. J. Mark. 1988, 52, 2-22. [CrossRef]

42. Duman, T.; Mattila, A.S. The Role of Affective Factors on Perceived Cruise Vacation Value. Tour. Manag. 2005, 26, 311-323. [CrossRef]

43. Kim, S.-H.; Holland, S.; Han, H.-S. A Structural Model for Examining How Destination Image, Perceived Value, and Service Quality Affect Destination Loyalty: A Case Study of Orlando. Int. J. Tour. Res. 2013, 15, 313-328. [CrossRef]

44. Wang, B.; Yang, Z.; Han, F.; Shi, H. Car Tourism in Xinjiang: The Mediation Effect of Perceived Value and Tourist Satisfaction on the Relationship between Destination Image and Loyalty. Sustainability 2016, 9, 22. [CrossRef]

45. Yi, S.; Day, J.; Cai, L.A. Exploring Tourist Perceived Value: An Investigation of Asian Cruise Tourists' Travel Experience. J. Qual. Assur. Hosp. Tour. 2014, 15, 63-77. [CrossRef]

46. Eid, R.; El-Gohary, H. Muslim Tourist Perceived Value in the Hospitality and Tourism Industry. J. Travel Res. 2015, 54, 774-787. [CrossRef]

47. Prebensen, N.K.; Woo, E.; Chen, J.S.; Uysal, M. Motivation and Involvement as Antecedents of the Perceived Value of the Destination Experience. J. Travel Res. 2013, 52, 253-264. [CrossRef]

48. Shen, Y.S. Perceived Value in Tourism Experience; Tourism Travel and Research Association: Advancing Tourism Research Globally: Whitehall, CA, USA, 2016; Volume 8, pp. 1-12.

49. Hu, H.-H.; Kandampully, J.; Juwaheer, T.D. Relationships and Impacts of Service Quality, Perceived Value, Customer Satisfaction, and Image: An Empirical Study. Serv. Ind. J. 2009, 29, 111-125. [CrossRef]

50. Jeong, Y.; Kim, S. A Study of Event Quality, Destination Image, Perceived Value, Tourist Satisfaction, and Destination Loyalty among Sport Tourists. Asia Pac. J. Mark. Logist. 2020, 32, 940-960. [CrossRef] 
51. Zeithaml, V.A.; Berry, L.L.; Parasuraman, A. The Behavioral Consequences of Service Quality. J. Mark. 1996, 60, 31-46. [CrossRef]

52. Chang, S.-H.; Lin, R. Building a Total Customer Experience Model: Applications for the Travel Experiences in Taiwan's Creative Life Industry. J. Travel Tour. Mark. 2015, 32, 438-453. [CrossRef]

53. Kim, S.; Kim, S. Perceived Values of TV Drama, Audience Involvement, and Behavioral Intention in Film Tourism. J. Travel Tour. Mark. 2018, 35, 259-272. [CrossRef]

54. Lai, I.K.W.; Hitchcock, M.; Lu, D.; Liu, Y. The Influence of Word of Mouth on Tourism Destination Choice: Tourist-Resident Relationship and Safety Perception among Mainland Chinese Tourists Visiting Macau. Sustainability 2018, 10, 2114. [CrossRef]

55. Wang, C.; Lu, L.; Xia, Q. Impact of Tourists' Perceived Value on Behavioral Intention for Mega Events: Analysis of Inbound and Domestic Tourists at Shanghai World Expo. Chin. Geogr. Sci. 2012, 22, 742-754. [CrossRef]

56. Fu, Y.; Liu, X.; Wang, Y.; Chao, R.-F. How Experiential Consumption Moderates the Effects of Souvenir Authenticity on Behavioral Intention through Perceived Value. Tour. Manag. 2018, 69, 356-367. [CrossRef]

57. Caber, M.; Albayrak, T.; Crawford, D. Perceived Value and Its Impact on Travel Outcomes in Youth Tourism. J. Outdoor Recreat. Tour. 2020, 31, 100327. [CrossRef]

58. Xie, P.F.; Luo, J. Investigating Visitor Attitudes towards the Reopening of a Theme Park: An Application of the Push-Pull-Mooring Model. J. Travel Tour. Mark. 2021, 38, 867-880. [CrossRef]

59. Ong, C.-E. 'Cuteifying'Spaces and Staging Marine Animals for Chinese Middle-Class Consumption. Tour. Geogr. 2017, 19, 188-207. [CrossRef]

60. Hair Jr, J.F.; Hult, G.T.M.; Ringle, C.M.; Sarstedt, M. A Primer on Partial Least Squares Structural Equation Modeling (PLS-SEM); Sage Publications: Thousand Oaks, CA, USA, 2021.

61. Hair Jr, J.F.; Matthews, L.M.; Matthews, R.L.; Sarstedt, M. PLS-SEM or CB-SEM: Updated Guidelines on Which Method to Use. Int. J. Multivar. Data Anal. 2017, 1, 107-123. [CrossRef]

62. Ringle, C.M.; Wende, S.; Becker, J.-M. SmartPLS 3. SmartPLS GmbH, Boenningstedt. J. Serv. Sci. Manag. 2015, 10, 32-49.

63. Podsakoff, P.M.; MacKenzie, S.B.; Lee, J.-Y.; Podsakoff, N.P. Common Method Biases in Behavioral Research: A Critical Review of the Literature and Recommended Remedies. J. Appl. Psychol. 2003, 88, 879. [CrossRef] [PubMed]

64. Henseler, J.; Ringle, C.M.; Sarstedt, M. A New Criterion for Assessing Discriminant Validity in Variance-Based Structural Equation Modeling. J. Acad. Mark. Sci. 2015, 43, 115-135. [CrossRef]

65. Cohen, J. Statistical Power Analysis for the Behavioral Sciences, 2nd ed.; L. Erlbaum Associates: Hillsdale, NJ, USA, 1988; ISBN 978-0-8058-0283-2.

66. Piramanayagam, S.; Rathore, S.; Seal, P.P. Destination Image, Visitor Experience, and Behavioural Intention at Heritage Centre. Anatolia 2020, 31, 211-228. [CrossRef]

67. Iglesias-Sánchez, P.P.; Correia, M.B.; Jambrino-Maldonado, C.; de las Heras-Pedrosa, C. Instagram as a Co-Creation Space for Tourist Destination Image-Building: Algarve and Costa Del Sol Case Studies. Sustainability 2020, 12, 2793. [CrossRef]

68. Jin, N.; Lee, S.; Lee, H. The Effect of Experience Quality on Perceived Value, Satisfaction, Image and Behavioral Intention of Water Park Patrons: New versus Repeat Visitors. Int. J. Tour. Res. 2015, 17, 82-95. [CrossRef]

69. Yen, C.-H.; Teng, H.-Y. Celebrity Involvement, Perceived Value, and Behavioral Intentions in Popular Media-Induced Tourism. J. Hosp. Tour. Res. 2015, 39, 225-244. [CrossRef]

70. Jin, N.; Lee, H.; Lee, S. Event Quality, Perceived Value, Destination Image, and Behavioral Intention of Sports Events: The Case of the IAAF World Championship, Daegu, 2011. Asia Pac. J. Tour. Res. 2013, 18, 849-864. [CrossRef] 